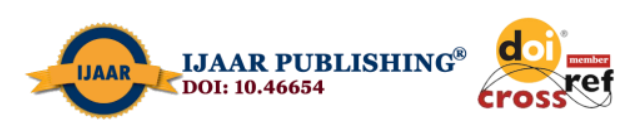

International Journal of Advanced Academic Research (Social and Management Sciences) | ISSN: 2488-9849

Vol. 6, Issue 6 (June, 2020) | www.ijaar.org

Journal DOI: 10.46654/ij.24889849

Article DOI: 10.46654/ij.24889849.s668

\title{
INTELLECTUAL CAPITAL AND EMPLOYEE PERFORMANCE IN SELECTED MANUFACTURING COMPANIES IN EDO STATE
}

\author{
OJOH JAMES \\ Department of Public Administration, \\ School of Humanities and Social Sciences, \\ Delta State Polytechnic, Ozoro, Nigeria. \\ $\&$ \\ IBEGBULEM ANDREAS BRUTUS \\ Department of Business Administration and Management, \\ School of Business Studies, \\ Delta State Polytechnic, Ozoro, Nigeria.
}

\begin{abstract}
The issue of quality management, production process timeliness and inability to signal competence to external constituencies are the problems these manufacturing bottling companies grapple with as the business environment keeps changing and getting fiercer in its competition level due to the trend of globalization. The broad objective of this study is to determine the influence of intellectual capital on employee performance in selected manufacturing bottling companies in Edo State. The study specifically seeks to determine the nature of relationship existing between human capital and product innovation, to ascertain how organizational capital is related to creative operations and to determine the extent to which Social Capital influences Signal of Competence in the manufacturing bottling Companies. Survey research design was utilized. 291 structured copies of questionnaire were used to collect data and data were analyzed using mean and standard deviation. Pearson product moment Correlation was used to test the hypotheses. The findings revealed that human capital positively and significantly influences employee's performance towards achievement of knowledge productivity for organizational goals attainment. This study concluded that for an organization to remain relevant in the business environment, such organization must fully tap into resources both within and outside the organization. The study recommends that the management of the companies should continually engage in rethinking and re-auditing of self, employees and the business environment for opportunities available.
\end{abstract}

Keywords: Intellectual capital, globalization, employees, competence, environment, performance. 


\section{INTRODUCTION}

Today's production and operations managers in Nigerian manufacturing firms face many challenges with respect to quality demand of products from members of the public. As globalization takes place, the market is getting more and more competitive. Manufacturing firms are faced with tremendous pressure to succeed in the market place with increasing productivity, product quality and market shares of competitors. The well-known epileptic power supply in the country is a problem in the manufacturing sector as virtually all manufacturing companies rely on alternative source of power supply. This option of these manufacturing bottling companies relying on alternate source of power supply to perform production process will not only affect the cost of production but on the long run affect the price of the products resulting to loss of customers and overall economic cost for these companies.

More so, the resultant effect of globalization has led to severe and fierce domestic and universal competition, acute decline in profit margin, escalation of input prices among manufacturing companies as productivity is a crucial concern for business organizations, because it may be the most important driver for achieving satisfactory results and significant cost-advantage over competitors. The issue of quality management, production speed, signal of competence and technological adaptation is another problem the manufacturing bottling companies are facing as the business environment keep changing and getting more fierce in its competition level.

As these bottling companies grapple with the issue of appropriate production scheduling as a factor of meeting product demand from the customers, the issue of production efficiency is ignored. This act of unprofessionalism constitutes a problem as the expectations of customers on quality product are high and these bottling companies suffered visible quality defect in the products ranging from improper capping of the bottled products, inequalities in volume, measurement of same capacity products, taste defect and other production process challenges which is a sign of lack of competences in the processes involved in the transformation of the raw materials into finished goods.

Unlike before when there was monopoly, the business environment is no longer a blue ocean but a red ocean where every organisation seeks means to edge out their competitors out of business. Within this research, the process of transforming knowledge into value which is knowledge productivity is what these firms desired of their employee. It is in the light of the aforementioned problems identified in these manufacturing bottling companies that this study seeks to proffer solutions.

\section{Objectives of the Study}

The broad objective of this study was to determine how Intellectual Capital influences Employee Performance in the companies of focus. The specific objectives of this study are:

- To determine the nature of relationship existing between human capital and product innovation in the selected manufacturing bottling companies.

- To ascertain how organizational capital is related to creative operations in the selected manufacturing bottling companies. 
- To determine the extent to which social capital influences signal of competence in the selected manufacturing bottling companies.

\section{Research Questions}

To achieve the purpose of this work, the following questions were raised.

- What is the nature of relationship existing between human capital and product innovation in the selected manufacturing bottling companies?

- How is organizational capital related to creative operations in the selected manufacturing bottling companies?

- To what extent has social capital influenced the signal of competence in the selected manufacturing bottling companies?

\section{Hypotheses}

The following research (alternate) hypotheses were formulated for testing:

- There is a positive relationship between human capital and product innovation.

- Organisational capital is positively related to creative operations.

- Social capital has a positive significant influence on signal of competence.

\section{CONCEPTUAL REVIEW}

\section{Intellectual Capital}

The concept of intellectual capital (IC) is grounded in several developments which are closely related to the characteristics of the knowledge economy. The term "Intellectual Capital" is used as a synonym for intangible or knowledge assets. Intellectual capital from viewpoint of organizational resources, related to creating wealth investment in knowledge, moral assets, and experience (Stewart, 2013). Intellectual capital is defined as a group of knowledge assets and is considered among the features of that organization and significantly leads to improvement of competitive situation of organization through increase of added value for key stakeholders of organization (Marr, 2005).

Even after more than a decade, the term intellectual capital has numerous interpretations and definitions. This divergence can be explained by the fact that the field is still in its "embryonic stage" (Bontis, 2012). Andriessen (2010) add to this that each author just wants "to convey a specific message that he thinks is important". However, despite the differences, there is also a great deal of agreement about the nature of intellectual capital. Stam (2007) present the core-elements of agreement as;

\section{- Intellectual capital is about intangibles.}

An intangible is something which is "hidden or not-material", which is "difficult to understand" and which "cannot be known by the senses", although "it is known to be real" (Longman Dictionary). Intellectual capital presents intangibles as an object so that they can be recognized and understood (Mouritsen, Bukh, Larsen, \& Johansen, 2012). 


\section{Theoretical Framework}

This work is anchored on the system theory developed by Chester Barnard (1938) and relational coordination theory by Gittell (2011). The system theory advocates that organization in search for solutions to organizational problems, should look beyond one single rigid solution; rather they should examine all critical variables both in the internal and the external environment of the organization. This is because they all interact together for the achievement of organizational goals and objectives. The perception of an organization as a single unit with lot of inter-related parts will assist managers in having a better perspective of their organization which in turn will help them in providing a better method of analyzing and solving problems.

The basic assumptions of this theory are;

- A system is greater than the sum of its part.

- A typical organization is a system consisting of a set of interrelated parts, with each part forming a sub-system of a whole system.

The relational coordination theory is simply communicating and relating for the purpose of task integration. Together, these mutually reinforcing relationship and communication ties form the basis for coordinated collective action, driving high performance outcomes. The approaches to relational coordination theory are:

- Relational coordination theory identifies specific communication and relationships ties needed to drive coordination and performance. These relationships include shared goals that transcend participants' specific functional goals, shared knowledge that enables participants to see how their specific tasks interrelate with the whole process, and mutual respects that enables participants to overcome the status barriers that prevent them from seeing and taking account of the work of others. Together these three relational dimensions support communication that is frequent, timely, accurate and focused on problem-solving rather than blaming.

- Relational coordination theory focuses on work relationships. These ties are measured between work roles, rather than as personal ties.

Relational coordination theory drives critical performance outcomes. Relational coordination is carried out through direct contact among workers at the front-line, through networks that cut across functional silos at the point of contact with the customer. Relational coordination therefore improves performance of a work process by improving the work relationships between people (shared goals, shared knowledge, mutual respect) who perform different functions in that work process, leading to higher quality communication. Participants can manage their interdependencies more directly, in a more seamless way, with fewer redundancies, lapses, errors and delays.

This theory suites this work as it advocates that organization in search for solutions to organizational problems, should look beyond one single rigid solution; rather they should examine all critical variables both in the internal and the external environment (human capital, social capital and organizational capital) of the organization. The objectives of this study focused on the interdependence of all the forces that constitute the business 
environment. From a system perspective, intellectual capital has three components: Human capital, organizational capital and social capital that have been considered to be interdependent in this study. The holistic approach to intellectual capital between the aforementioned capitals is because they all interact together and must be coordinated for the achievement of organizational goals and objectives. Patton (2011) described how human capital resembles a root, absorbing all nutrition, then organizational capital is like a trunk, providing nutrient transit, and social capital is like the leaves, conveying environmental elements.

\section{Human capital}

This first class represents anything related to the people within the organization the employees, their tacit knowledge, skills, experience and attitude. There are many definitions of human capital in the literature. The term human capital refers to the knowledge, seniority, mobility rate, skills, and experiences of the entire organization's staff and management. Arbab and Abbasi (2013) define human capital as a set of tacit knowledge and explicit knowledge of employees which is considered value for organization. On the other hand, human capital is defined as a combination of knowledge, skill, initiative and ability of employees for duties (Bontis, 2012).

However, one of the most useful and widely used is that by the OECD (2011), which affirm that human capital is the "knowledge, skills, competencies and attributes embodied in individuals that facilitate the creation of personal, social and economy well-being". Hence, the education, experience and abilities of an individual have an economic value for the individual, for employers and for the economy as a whole. It refers to the knowledge that employees possess as well as their ability to generate it, which is useful for the firm, and includes individual values and attitudes, aptitudes, and know-how (Subramaniarn \& Youndt, 2015). Human capital reflects the overall skill, expertise, and knowledge level of an organization's employees.

\section{Employee Performance}

Existing literature presented employee performance as a complex and multidimensional construct that can be defined and accessed in varying ways in the manufacturing firms. For all that, employee performance can be defined in terms of quantifiable outcomes of work behaviours and in terms of behavioural dimensions (e.g., work related communication, decision making, attention to detail) that are less quantifiable. It can be defined solely in terms of task performance related to the activities that support the technical core of the organization and are normal part of the relevant job description but can also be defined as contextual performance related to the activities that support the social and psychological environment of the organization and its employees.

Employee performance in the manufacturing sector is interchangeably used as knowledge productivity. This is because the manufacturing sector heavily depends on the technical knowhow of the employee to remain relevant in the business environment. Employee performance in this context refers to the competence of individuals and groups to gradually improve and radically innovate operating procedures, products and services in order to help organization improve their knowledge productivity. 
Stam (2007) propose the knowledge productivity enhancer which includes acquiring subject matter expertise, learning to identify and solve problems, cultivating reflective skills, securing communication skills, acquiring skills for self-regulation of motivation, promoting peace and stability, and causing creative turmoil in order to stimulate innovation. Drucker (2002) argued that making knowledge productive is the responsibility of management and requires a systematic and organized application of knowledge to knowledge in the production based sector.

Employee Performance is the results of a person's activities in terms of performing the assigned duties at any given time, meeting the predictive criteria or key benchmarks in the presented framework. This framework acts as a means for judging the efficiency of the group members, institutes and organizations. The emphasis is on improvement, learning and development in order to achieve the overall business strategy and to create a high performance workforce (Dooley, 2012).

\section{Creative Operation}

Creative Operations is the field responsible for increasing timeliness, capacity and compliance in the creative production process (Thorntonon, 2014). He added operational efficiency to the creative workflow process by using tools, measurement, and best practices to streamline and structure the way creative work is produced in their organization. Creative operations sometimes hide behind other names, like Creative workflow and Work-inprogress.

Regardless of what terminology you are using, if your role is to add efficiency to one of those areas, and you are working to improve the timeliness, compliance or capacity of these things, you are working in creative operations. At the end of the day, anyone who is tasked with managing and improving the timeliness, capacity and compliance of the creative production process is working in creative operations, regardless of industry or company size.

Creative operations, and the operational efficiency is the key to increasing your production capacity and delivering more approved assets on time, while remaining compliant with all of your required processes (Thorntonon, 2014). Creative operations represents a systems-based approach for managing innovation and creativity within creative industries or creative service groups, applying the basic principles of operations management to the timely, on-budget delivery of advertising, branding, customer engagement, packaging, or promotional projects to clients.

\section{Enhanced Product Innovation}

Product innovation is the creation and subsequent introduction of a good or service that is either new, or an improved version of previous goods or services (Wong, 2014). This is broader than the normally accepted definition of innovation that includes the invention of new products which, in this context, are still considered innovative. Product innovation is defined as the development of new products, changes in design of established products, or use of new materials or components in the manufacture of established products.

Hoang (2010) define product innovation as the development and market introduction of a new, redesigned or substantially improved good or service. Examples of product innovation by a business might include a new product's invention; technical specification and quality 
improvements made to a product; or the inclusion of new components, materials or desirable functions into an existing product.

Product innovation, alongside cost-cutting innovation and process innovation are three different classifications of innovation which aim to develop a company's production methods (Wong, 2014). Thus, product innovation can be divided into two categories of innovation: radical innovation which aims at developing a new product, and incremental innovation which aims at improving existing products. Product innovations include introducing new products, enhanced quality and improving its overall performance.

\section{Signals of Competences to External Constituencies}

Signals of competences which are also known as tacit signal are human-based guiding opinions that rise from situation based tacit knowledge related to organization human competencies. Through its work and interactions with others, a task unit provides a signal of its competence that may be only partially related to the inherent quality of its work, especially when it is difficult for outsiders to measure that quality directly, as is the case for much knowledge work in professional services firms (Podolny, 2014).

Signals of competences are utilized as organization development inquiries in connection to the development process for implementing optimal improvement actions in the workplace level. Optimal workplace innovations are collectively agreed to be the development actions with the best value for improving the working society competencies and performance. (Kesti \& Syvajarvi, 2010).

A task unit that is able to signal that it is highly competent stands to benefit because it is likely to develop a favorable reputation among its constituencies, including external customers. In the manufacturing firms, for instance, signals of competence can make an important difference to the chances of' winning more customers (Kesti, 2010). Again, this task outcome has beneficial by products; since the firm's positive market reputation grows as customers pass such reputations along to other potential customers. Signals of competences are guiding insights stemming from the tacit knowledge of employees. Kesti (2010) developed a scientifically tested method for identifying tacit signals.

\section{Intellectual Capital and Employee Performance}

In the view of Patton (2011), the productivity of a firm lies more on its intellectual capital and system capabilities than on its physical assets. Bontis (2011) argues that leveraging knowledge assets is the key to a firm's prosperity. Intellectual capital has received considerable attention from academics. The economist Galbraith (2000) was the first to propose the intellectual capital concept, and described intellectual capital as behaviour that requires the exercise of the brain.

Intellectual capital was not understood as static intellect, but rather as demanding dynamic intellect-creating activities. It is assumed that competitive advantage depends on how efficiently the firm builds, shares, leverages, and uses its knowledge. Specifically, a systematic interpretation of intellectual capital is adopted by identifying three main components: human capital, organizational capital, and social capital, all of which have been frequently cited in the literature. 


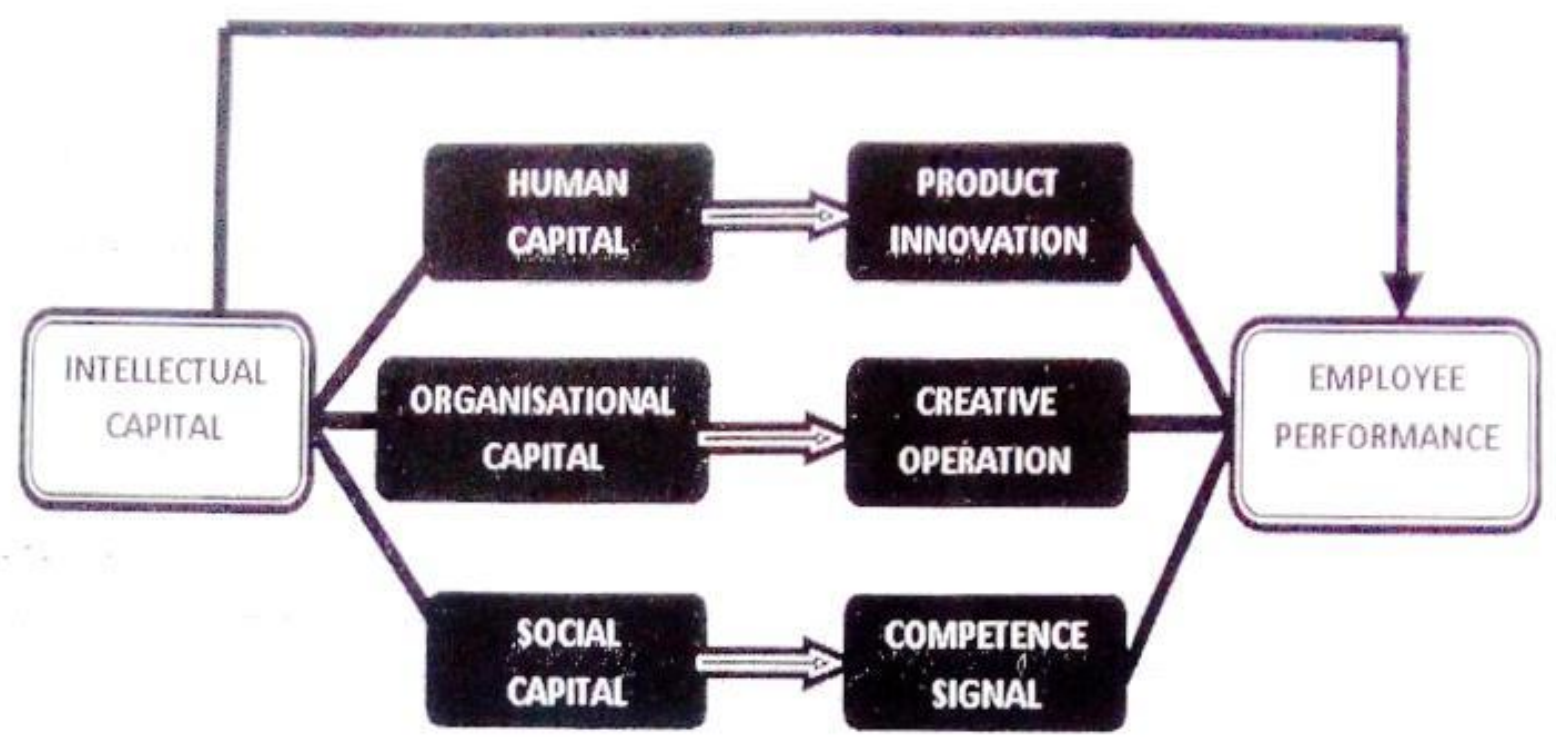

Figure 1: Conceptualized Intellectual Capital and Performance Model

Source: Researchers (2020).

From the above figure, the components of intellectual capital influence employee performance directly. However, these influences are not always isolated, given that human capital, organizational capital, and social capital are often intertwined in organizations. Therefore, their interrelationships also play an important role in shaping these influences. It is known that organizations adopt different approaches for accumulating and utilizing their knowledge, and that these approaches present themselves as different aspects of intellectual capital, i.e., human, organizational, and social capital (Davenport \& Prusak, 2013; Nahapiet \& Ghoshal, 2012). It is also widely accepted that an organization's capability to innovate is closely tied to its intellectual capital (Subramaniam and Youndt, 2015). At the individual level, knowledge generation and transfer is a function of willingness.

From a managerial and economic perspective, productivity is mainly a function of three variables: technology, labor and organization. Any variable, individually taken, adds to or deducts from productivity: up-to-date, modern equipment and systems; professional, skilled human capital; coherent and adequate coordination, efficient work routines, each can be a source of incremental and dramatic change in productivity.

Apart from the relative contribution of each variable, the interplay and the mutual impact of each other fuel changes in productivity both at macro and micro level. Making knowledge workers productive requires changes in basic attitudes, whereas making the manual worker more productive only requires telling the worker how to do the job (Drucker, 2002). In addition, such attitudinal changes are not to be made only on the part of individual knowledge workers, but also of the total organization.

Individuals and their associated human capital may encourage the questioning of established norms and originate new ways of thinking, but their unique ideas often need to connect with one another for radical breakthroughs to occur. The extent to which product innovation, creative operation and signal of competence are valuable to the firm depends on contextual 
factors, including the aspects of products and services that are most valued in the market, the extent of competition, and the rate by which knowledge can be replicated by competitors (Haas \& Hansen, 2015). In this sense, like other forms of productivity, employee performance is related to the ultimate value derived from leveraging on the firm's resources for the achievement of the organizational goals.

\section{Empirical Review}

Many scholars/researchers have investigated intellectual capital an employee performance using different approach. Ekwe (2013) did a research on the effect of Intellectual Capitals on Employee Productivity of Banks in Developing Economies: The Nigeria Experience. The study uses the Value Added Intellectual Coefficient (VAIC) Model to investigate the effect of the Intellectual Capital indices (i.e. Human Capital Efficiency, Structural Capital Efficiency and the Capital Employed Efficiency) on the Employee Productivity of banks in Nigeria. The data were collected from the annual reports of six banks and analysis was conducted using longitudinal time series data generated from the annual reports and accounts of the selected banks in Nigeria spanning from year 2000 to 2011. The multiple regression analysis method was adopted for the test of the hypothesis. The SPSS statistical software (version 17.0) was used for the data analysis. The study showed that there was a positive and significant relationship between components of VAIC and employee productivity of the banks in Nigeria (VIAC coefficient $=1.186, \mathrm{R} 2 \mathrm{c}=0.806, \mathrm{R} 2 \mathrm{t}=0.49, \mathrm{P}<0.05)$. From the result stated above, it is thus established that indeed intellectual capital has positive and significant effect on Employee Productivity of banks in Nigeria.

Al-Fadel (2012) studied the relationship between intellectual capital and value creation. The study highlighted the role of Intellectual Capital and how it is important to create the organization's value. The study also concluded that Intellectual Capital can't be established by the investment volume, but through the intangible value of the organization since this value is coming from the employees' mind toward innovation and that requires suitable organization climate to provide the main requirements for strong and healthy relations between the management and the workforce.

Salman, Mansour and Babatunde (2012) investigated the impact of intellectual capital on return on assets in Nigerian manufacturing companies. Their results show that a relationship exists between intellectual capital components efficiencies and company performance. Furthermore, human capital influences productivity performance of the sample companies more than structural and physical capital.

Goh (2014) did a study on the impact of intellectual capital on Malaysian domestic and foreign bank using Value Added Intellectual Coefficient to measure the impact of IC i.e. (Human Capital Efficiency, Structural Capital Efficiency and Capital Employed Efficiency). $\mathrm{He}$ argued that Human Capital Efficiency (HCE) in terms of value creation is more influenced both in domestic and foreign banks. He further explained that investment employed in human capital is more returnable than structural and physical capital.

Ahmad and Mushraf (2011) studied the relationship between Intellectual Capital and Business Performance: An empirical study in Iraqi industry. The purpose of this study is to explore the relationships between intellectual capital and business performance in Iraqi industry. The main objective of this study is to investigate whether intellectual capital has a 
direct effect on business performance. However, a review of the management literature reveals that the relationship between intellectual capital and business performance is still vague. In the study, the responses and information collected was collected from 191 respondents. A correlation coefficient among the four variables of intellectual capital namely (Human capital, Customers capital, Relational capital and Structural capital) and Business performance reveals that positive relationship exists among them. The result of this study emphasize there is positive relationship between intellectual capital (consists of customer capital, human capital, structural capital, relation capital) and businesses performance (consists of innovation, rate of new product development, customer satisfaction, customer retention and operating costs).

\section{Research Design}

The study employed the use of descriptive survey research design. This design was adopted so as to aid the collection of data from sampled respondents through administration of questionnaire instrument.

\section{Population}

The study population consists of 13,458 employees of the two selected manufacturing bottling companies producing in Edo State.

\section{Table 3.1: Company's Population}

\section{S/N COMPANY}

$1 \quad$ Nigerian Bottling Company Plc.

2 Seven up Bottling Company Plc.

Total

Source: Companies Website.

\section{Sample Size and Sampling Techniques}

The sample size consists of 385 participants which were drawn from the population using taro Yamane formula $\left(\mathrm{n}=\mathrm{N} / 1+\mathrm{N}\left(\mathrm{e}^{2}\right)\right.$, where $\mathrm{n}=$ Sample size, $\mathrm{N}=$ Population, $\mathrm{e}=$ error margin at 0.05). Disproportionate stratified random sampling technique was used to select the participant. Bowley population allocation formula $(\mathrm{nNh} / \mathrm{N}$, where $\mathrm{n}=$ Sample size, $\mathrm{Nh}=$ Population of each organization, $\mathrm{N}=$ Total Population) was used to determine the number of participant to be drawn from each organisation.

Allocation for Nigerian Bottling Company Plc

$\frac{385(10,000)}{13458}=286$

\section{Allocation for Seven up Bottling Company Plc}

$\frac{385(3,458)}{13458}=99$

\author{
STAFF STRENGTH \\ 10,000 \\ 3,458 \\ 13,458
}




\section{Sources of Data}

Data were sourced from primary and secondary sources. The primary source was through structured questionnaire the researcher distributed on the field while the secondary source of data were elicited from online journals, articles, company's websites and textbooks.

\section{Tools of Data Collection}

Data were collected from the employees of the two selected manufacturing bottling companies using a well-structured questionnaire instrument. The items of the questionnaire were structured on a 4 point Likert scale so as to extract specific response from respondent without any neutral option. Out of 385 copies administered, 291 which represent 75.6 per cent copies of the questionnaire were found useful for analysis.

\section{Validity of the Instrument}

The instrument that was used to collect data for the study was subjected to content and face validity by the researcher, and some experts in management sciences to ensure that the items of the questionnaire capture the variables of the study. The variables are the objectives, research questions and the hypotheses of the study which is well structured on the basis of the related literature awareness. They also ensure that the questions were relevant and unambiguous. The items included in the measure adequately represent the universe of questions that was asked.

\section{Reliability of the Instrument}

The Intellectual Capital Scale (ICS) research instrument was adapted from other researchers' study (Ferreira, 2011; Ferreira, Costa, \& Santos, 2010). A 16 item scale that measures three dimensions of intellectual capital: (a) Customer Capital; (b) Structural Capital; and (c) Human Capital. All items consisted of affirmative sentences associated with a seven alternative Likert answer scale, ranging from 1 (totally disagree) to 7 (totally agree). Scale dimensions reported appreciable psychometric values with Cronbach Alphas ranging from .62 for Structural Capital to .92 for Human Capital (Adler \& Kwon, 2002; Atrill, 1998; Bontis, 1998; Dzinkowski, 2000; Lynn, 1998; Youndt \& Snell, 2004; Ferreira, 2010; Choudhury, 2010).

After few modifications on the instrument, the reliability of the research instrument was therefore subjected to pilot study. The logic and sequence of the research instrument which is the reliability test was confirmed by coefficient alpha, which measures internal consistency using the Spearman Brown Split Half Likert Scale Test (4 Likert Scale). Reliability analysis showed that the coefficient alpha of the questionnaire were 0.858 indicating that the variables of questionnaire were highly reliable.

\section{Method of Data Analysis}

The study uses descriptive and inferential analysis techniques to analyze data. The descriptive statistics used are mean and the standard deviations which indicated the average performance of a group or a measure of some variables of the research questions. The inferential statistics used was the Pearson Product Moment Correlation using the SPSS software Version 20. 
Decision Rule: Correlation analysis reports the interdependence of the study variables. Statistical correlation is significant if coefficient is more than 0.5. Moreover, if p-value is low (under 0.01 ), it means that the correlation actually exists. In case p-value is high, it cannot be determined that the correlation actually exists.

\section{Operational variables for independent variable}

- Human Capital - employee skills, experience, qualification and initiative.

- Organisational Capital - culture, process, policy, patent, structure, organizational learning, information system.

- Social Capital - marketing capabilities, stakeholder relationship, strategic partnership, loyalty, market intensity.

\section{Operational variables for dependent variable}

- Product Innovation - product improvement, rebranding, design.

- Creative Operations - timeliness, compliance, production capacity, quality management.

- Signal of Competences - customer relationship, delivery schedule, demand uncertainty.

\section{DATA PRESENTATION AND ANALYSIS}

In analyzing the data, the study used descriptive and inferential analysis. The descriptive statistics used are mean and the standard deviations which indicated the average performance of a group or a measure of some variables of the research questions. The inferential statistics used was the Pearson Product Moment Correlation using the SPSS software Version 20 for the manufacturing bottling companies under study.

Research Question One: What is the nature of relationship existing between Human Capital and Product Innovation?

Table 4.1: Descriptive Statistics of Research Question

\begin{tabular}{|c|c|c|c|c|c|c|}
\hline & $\mathbf{N}$ & Minimum & Maximum & Sum & Mean & Std. Deviation \\
\hline QUE00001 & 291 & 1.00 & 4.00 & 894.00 & 3.0722 & .69848 \\
\hline QUE00002 & 291 & 1.00 & 4.00 & 984.00 & 3.3814 & .85230 \\
\hline QUE00003 & 291 & 1.00 & 4.00 & 895.00 & 3.0756 & .76640 \\
\hline QUE00004 & 291 & 1.00 & 4.00 & 880.00 & 3.0241 & .76301 \\
\hline QUE00005 & 291 & 3.00 & 4.00 & 1073.0 & 3.6873 & .46440 \\
\hline QUE00016 & 291 & 1.00 & 4.00 & 860.00 & 2.9553 & .93665 \\
\hline QUE00017 & 291 & 3.00 & 4.00 & 1023.0 & 3.5155 & .50062 \\
\hline QUE00018 & 291 & 1.00 & 4.00 & 921.00 & 3.1649 & .95788 \\
\hline QUE00019 & 291 & 1.00 & 4.00 & 826.00 & 2.8385 & 1.06901 \\
\hline QUE00020 & 291 & 3.00 & 4.00 & 1073.0 & 3.6873 & .46440 \\
\hline Valid & 291 & & & & & \\
\hline
\end{tabular}

(listwise)

Source: Field Survey 2020, SPSS Ver. 20 Computation

The descriptive table 4.1 shows the mean score and the standard deviation of the questionnaire items which is in accordance with the research questions stated in this study. The 4points Likert scale was used and the decision rule is to accept any item that falls within the mean of 2.5 and above significant. 
Research Question Two: How is Organizational Capital related to Creative Operations?

Table 4.2: Descriptive Statistics of Research Question

\begin{tabular}{|c|c|c|c|c|c|c|c|}
\hline & & $\mathbf{N}$ & Minimum & Maximum & Sum & Mean & Std. Deviation \\
\hline QUE00006 & & 291 & 1.00 & 4.00 & 981.00 & 3.3711 & .89812 \\
\hline QUE00007 & & 291 & 3.00 & 4.00 & 1123.00 & 3.8591 & .34851 \\
\hline QUE00008 & & 291 & 1.00 & 4.00 & 847.00 & 2.9107 & .97145 \\
\hline QUE00009 & & 291 & 2.00 & 4.00 & 1112.00 & 3.8213 & .39264 \\
\hline QUE00010 & & 291 & 1.00 & 4.00 & 930.00 & 3.1959 & .71880 \\
\hline QUE00021 & & 291 & 1.00 & 4.00 & 923.00 & 3.1718 & 1.05276 \\
\hline QUE00022 & & 291 & 3.00 & 4.00 & 974.00 & 3.3471 & .47686 \\
\hline QUE00023 & & 291 & 1.00 & 4.00 & 774.00 & 2.6598 & 1.08805 \\
\hline QUE00024 & & 291 & 1.00 & 4.00 & 664.00 & 2.2818 & 1.16396 \\
\hline QUE00025 & & 291 & 1.00 & 4.00 & 727.00 & 2.4983 & 1.13980 \\
\hline $\begin{array}{l}\text { Valid } \\
\text { (listwise) }\end{array}$ & $\mathrm{N}$ & 291 & & & & & \\
\hline
\end{tabular}

Source: Field Survey 2020, SPSS Ver. 20 Computation

The descriptive table 4.2 shows the mean score and the standard deviation of the questionnaire items which is in accordance with the research questions stated in this study. The 4points Likert scale was used and the decision rule is to accept any item that falls within the mean of 2.5 and above as significant.

Research Question Three: To what extent has Social Capital influenced the Signal of Competence?

Table 4.3: Descriptive Statistics of Respondents Response

\begin{tabular}{|c|c|c|c|c|c|c|c|}
\hline & & $\mathbf{N}$ & Minimum & Maximum & Sum & Mean & Std. Deviation \\
\hline QUE00011 & & 291 & 1.00 & 4.00 & 909.00 & 3.1237 & .59754 \\
\hline QUE00012 & & 291 & 1.00 & 4.00 & 1025.00 & 3.5223 & .69631 \\
\hline QUE00013 & & 291 & 1.00 & 4.00 & 780.00 & 2.6804 & .82478 \\
\hline QUE00014 & & 291 & 1.00 & 4.00 & 587.00 & 2.0172 & .88066 \\
\hline QUE00015 & & 291 & 1.00 & 4.00 & 896.00 & 3.0790 & .79042 \\
\hline QUE00026 & & 291 & 1.00 & 4.00 & 714.00 & 2.4536 & 1.19211 \\
\hline QUE00027 & & 291 & 3.00 & 4.00 & 1071.00 & 3.6804 & .46712 \\
\hline QUE00028 & & 291 & 1.00 & 4.00 & 985.00 & 3.3849 & .77213 \\
\hline QUE00029 & & 291 & 1.00 & 4.00 & 741.00 & 2.5464 & 1.13582 \\
\hline QUE00030 & & 291 & 1.00 & 4.00 & 770.00 & 2.6460 & 1.06762 \\
\hline Valid & $\mathrm{N}$ & 291 & & & & & \\
\hline
\end{tabular}

(listwise)

Source: Field Survey 2020, SPSS Ver. 20 Computation

The descriptive table 4.3 shows the mean score and the standard deviation of the questionnaire items which were in accordance with the research questions stated in this study. The 4points Likert scale was used and the decision rule is to accept any item that falls within the mean of 2.5 and above as significant. 


\section{Test of Hypotheses}

The inferential Statistics used was the Pearson Product Moment Correlation using the SPSS software Version 20.

\section{Hypothesis One}

There is a positive relationship between Human Capital and Product Innovation.

Table 4.4a: Correlations Result for Hypothesis 1

\section{Pearson Correlation}

HUMCAP Sig. (2-tailed)

$$
\mathrm{N}
$$

Pearson Correlation

PROINNO Sig. (2-tailed)

$\mathrm{N}$

\section{HUMCAP PROINNO}

1

$.911 "$

291

$.911 "$

1

.000

291

**. Correlation is significant at the 0.01 level (2-tailed).

Source: Field Survey 2020, SPSS Ver. 20 Computation

The Table 4.4a shows the p-value (0.000) is less than 0.01 (at a 2-tailed test) meaning that and Human Capital and Product Innovation are positively correlated with each other with the correlation coefficient of 0.911 . This connotes that with the increase of Human Capital, Product Innovation also increases. Findings show that the research hypothesis is accepted which state that there is a positive relationship between Human Capital and Product Innovation.

\section{Hypothesis Two}

Organizational Capital is positively related to Creative Operations.

Table 4.4b: Correlations Result for Hypothesis 2

\section{Pearson Correlation}

ORGCAP Sig. (2-tailed)

$\mathrm{N}$

Pearson Correlation

CREOPR Sig. (2-tailed)

$\mathrm{N}$
ORGCAP CREOPR

1 $.820 "$
.000

291

1

**. Correlation is significant at the 0.01 level (2-tailed).

Source: Field Survey 2020, SPSS Ver. 20 Computation

The Table $4.4 \mathrm{~b}$ shows the p-value (0.000) is less than 0.01 (at a 2-tailed test) meaning that Organizational Capital and Creative Operations are positively related to each other with the correlation coefficient of 0.820 . This connotes that with the increase of Organizational Capital, Creative Operations also increase. Findings show that the research hypothesis is accepted which state that Organizational Capital is positively related to Creative Operations. 


\section{Hypothesis Three}

Social Capital has a positive significant influence Signal of Competence.

Table 4.4c: Correlations Result for Hypothesis 3

\section{Pearson Correlation}

SOCCAP Sig. (2-tailed)

$\mathrm{N}$

Pearson Correlation

SIGCOMP Sig. (2-tailed)

$\mathrm{N}$

\section{SOCCAP SIGCOMP}

1

$.914 ”$

.000

291

291

$.914 "$

1

.000

291

**. Correlation is significant at the 0.01 level (2-tailed).

Source: Field Survey 2020, SPSS Ver. 20 Computation

Table $4.4 \mathrm{c}$ shows the p-value $(0.000)$ is less than 0.01 (at a 2-tailed test) meaning that Social Capital has positive significant influence on Signal of Competence with the correlation coefficient of 0.914. This connotes that with the increase of Social Capital, Signal of Competence also increases. Findings show that the research hypothesis is accepted which state that Social Capital has a positive significant influence on Signal of Competence.

\section{Summary of Findings}

The present study found each of the three components of intellectual capital to be related to increased employee performance. Hypothesis one result shows that there is a positive relationship between human capital and product innovation. With correlation coefficient of 0.911 at 0.01 level of significance (2-tailed test) which is greater than the p-value $(0.000)$. Since human capital reflects the overall skill, expertise, and knowledge level of an organization's employees, the findings revealed that experienced, skilled, and knowledge employees in the organization are the pacesetter for innovative product which range from rebranding of product, product improvement and other quality product enhancement. The finding widely accepts that an organization's capability to innovate is closely tied to its human capital. The outcome of the tested hypothesis

The result of hypothesis two shows a positive relationship between organizational capital and creative operation. This finding revealed the role the structures, systems, processes, values, cultures, patents and operations modus of the companies can help increase creative work among the employee of the organization. With correlation coefficient of 0.820 at 0.01 level of significance (2-tailed test) which is greater than the p-value (0.000), the findings revealed that production process timeliness compliance and capacity utilization which is the basis of creative works is positively influenced by the organisation's settings, strategy, culture, technology and processes.

Lastly, with correlation coefficient of 0.914 at 0.01 level of significance (2-tailed test) which is greater than the p-value $(0.000)$, the result of hypothesis three shows social capital has a positive significant influence on signal of competence. It was discovered that social capital also help to positively impact knowledge sharing to both internal and external constituencies of the organization and depict the organization's ability of competence signaling. Social Capital (strategic partnership, market intensity, customer relationship, suppliers' relationship 
and marketing capabilities) has a positive significant influence on the employee's ability to signal competence to external constituencies (during demand uncertainty response, delivery schedule, rush in other and value delivery).

From the findings of the three hypotheses tested, it is evident that the three components of intellectual capital significantly contribute to improvement and increment of the knowledge centered output of an employee in the business environment. The study also establishes that a well and properly coordinated intellectual capital will not only increase the performance of the employee in the organization of focus but it will also create a competitive edge for such organization.

It was also discovered that knowledge tied up in relationships among employees, customers, suppliers, alliance partners, and the like tends to lead to process and product innovations, better problem solving and thereby increasing production and service delivery efficiencies as well as customer satisfaction. Codified and documented knowledge with the use of patent helps in institutionalization of knowledge and knowledge sharing for further analysis by knowledge workers to increase the overall performance of the organizations.

\section{Conclusion}

This paper explores the influence of Intellectual Capital on Employee Performance in selected manufacturing bottling companies in Edo State. From the findings, this study concludes that if one accepts as true that knowledge has become an organization's main source of relative advantage and intellectual capital is the new wealth, the process of transforming this resource into wealth has become the new challenge. In the light of this, the ability to interrelate all business forces is the strength that can turn these challenges into opportunities. This study also concludes that for an organization to remain relevant in the business environment, such organization must fully tap into resources within the organization and the organization must as well leverage on the external constituencies that impact the organization.

\section{Recommendations}

Following from the conclusion derived from this study, the following recommendations are proffered:

- The management of these organizations should not only seek to recruit people with technical knowhow but they must also understand that, experienced, skilled and knowledge workers need tools and equipment that match their capabilities.

- The companies of focus should ensure that external stakeholders of the firms, especially the customers and contractors should be rightly fed with necessary information that will build trust in case of any production issues arising.

- The management of the companies should continually engage in rethinking and reauditing of self, employee and the business environment for opportunities available.

- Management should also ensure to codify and document knowledge to help in knowledge sharing for further analysis by knowledge workers within and outside the organization. 


\section{REFERENCES}

Ahmad, O. \& Mushra, F. (2011). "The relationship between intellectual capital and business performance: An empirical study in Iraqi industry", International Conference on Management and Artificial Intelligence IPEDR Vol. 6, IACSIT Press, Bali, Indonesia.

Al-Fadel, B. C. (2012). Reporting Intellectual capital to augment research, development and innovation in SME's. Report to the Commission of the High Level Expert Group on RICARDIS (No. EUR 22095 EN). Brussels: European Commission, DGResearch.

Arbab, S., Behrou, Z. \& Abbasi, M. (2009), Analyze the intellectual capital of universities from the perspective of knowledge management, Iran's First International Conference on Intellectual Capital.

Bontis, N. (2012). "Intellectual Capital: An exploratory study that develops measures and models". Journal of Management Decision 36(2): 63-76.

Choi, J., \& Wang, H., (2009). "Research notes and commentaries. Stakeholder relations and the persistence of corporate financial performance". Strategic Management Journal, No. 30, pp. 895-90 7.

Davenport, T.H, \&Prusak, L. (2013). Working Knowledge: How Organizations Manage What They Know, Boston, MA. Harvard Business School Press.

Dooley E. (2000). "Intellectual capital in the software industry: An empirical test". University of Washington Journal, 4 72-80.

Drucker, P.F. (2002). "Knowledge-worker productivity: The biggest challenge". California Management Review 41: 79-94.

Edvinsson, L., \& Malone, M. S. (1997). Intellectual capital - Realizing your company's true value by finding its hidden roots. New York, NY: Harper Business Press.

Fleetwood, S. \&Hesketh, A. (2010). Explaining the performance of human resource management, Cambridge University Press.

Galbraith, J. K. (2000). The New Industrial State: Harmondsworth; Penguin Publications.

Ghoshal, S., Bartlett, C. A., \& Moran, P. (2000). Value creation: The new millennium management manifesto. In S. Chowdhury (Ed.), Management 21C (pp. 121440). London: Financial Times/Prentice-Hall.

Gittell, J.H. (2011). Relational coordination: Coordinating work through relationships of shared goals, shared knowlede and mutual respect. In Kyriakidou, O. \&Ozbilgin, M. (Eds.), Relational perspectives in organizational studies: A research companion . London: Edward Elgar Publishers.

Goh, M.C (2014). "Intellectual capital profiles: An examination of Investments and returns". Journal of Management Studies 41(2): 335 -361. 
Gordon, P. (1996). Dow's journey to a knowledge value management culture". European. Management Journal 14 (1996) 365-373.

Gretchen, M. S. \& Kim S. C. (2011) Psychology, Organizational Psychology, Personality and Social Psychology. Online Publication Date: Nov. 2012.

Haas, M., \& Hansen M.T. (2005). "When using knowledge can hurt performance: The value of organizational capabilities in a management consulting company". Strategic Management Journal 26: 1-24.

Hackman, J.R. (1987). The design of work teams. Handbook of Organizational Behavior, Lorsch J. (ed). Englewood Cliffs, NJ; Prentice-Hall: 315-342.

Hoang, P. (2010). Business \& management. [Melton, Vic.]: IBID Press. p.686. ISBN 978 1876659639.

http://www.nigerianbottlingcompanyltd.com/Productsandbrands/Sparklingbeverages/CocaCola/

http://www.sevenup.org/home/

James, C., Mark, K. O. \& Karma, L. P. (2012). "Measuring intellectual capital: a new model and empirical study". Journal of Intellectual Capital. 5 (1), 2004.

Jyotirmayee, C.(2010). "Performance impact of intellectual capital: a study of Indian it sector". International Journal of Business and Management. 5,(9); September 2010.

Kesti, M., \&Syvajärvi, A. (2010). "Human tacit signals at organization performance development", Industrial Management \& Data Systems, Vol. 110 Iss: 2, pp.211 229DOI http://dx.doi.org/10.1108 /02635571011020313.

Levin, D.Z. (2000). Organizational learning and the transfer of knowledge: An investigation of quality improvement. Organization Science Journal 11: 630-647.

Loto, M. A. (2012). "Global economic downturn and the manufacturing sector performance in the Nigerian economy (a quarterly empirical analysis)". Journal of Emerging Trends in Economics and Management Sciences (JETEMS), 3(1):38-45.

Marr B (2004). "Measuring and benchmarking intellectual capital". Journal of Intellectual Capital, 11(6): 559-570.

Mavridis, D. G. (2010). "The intellectual capital performance of the Japanese banking sector". Journal of Intellectual Capital, 5 (1), 92-115.

McEvily, S., Das, S., \& McCabe, K. (2000). "Avoiding competence substitution through knowledge sharing”. Academy of Management Review 25: 294-312. 
Mouritsen, J. \& Larsen, T.H. (2014). "The 2nd wave of knowledge management: the management control of knowledge resources through intellectual capital information". Management Accounting Research, 3, (6) 371-394.

Mouritsen, J., Bukh, P. N., Larsen, H. T., \& Johansen, M. R. (2012). "Developing and managing knowledge through intellectual capital statements". Journal of Intellectual Capital, 3 (1), 10-29.

Nahapiet, Janine, Ghoshal, \&Sumantra. (2012). "Social capital, intellectual capital, and the organizational advantage". The Academy of Management Review,23, (2) (Apr., 2012), 242-266.

Onyeranti, G.A .20 12) "Concept of measurement of productivity", Department of Economics, University of Ibadan Press.

Pfeffer. J. \& Sutton. R.I. (2000). The knowing-doing gap: How smart companies turn knowledge into action. Harvard Business School Press.

Podolny, J.M. (2014)."Market uncertainty and the social character of economic exchange". Administrative Science Quarterly 39: 458-483.

Posted by Krissie Thorntonon June 26, 2014 http://blog.conceptshare.com/what-is-creativeoperations.

Rohana, N., \& Ibrahim, A. (2011). "The influence of intellectual capital on knowledge sharing: small and medium enterprises' perspective" .IBIMA Publishing Communications of the IBIMA http://www.ibimapublishing.com/journals/CIBlMA/cibima.html Vol. 2011 (2011), Article ID 444770, 13 pages.

Salman, R,M., Mansour, H,M., \& Babatunde A. D. (2012)'Impact of intellectual capital on return on assets in Nigerian manufacturing companies." Interdisciplinary Journal of research in business, Vol. 2, 2012, pp. 21-30.

Seetharaman A. BinZainiSooria H. H. \& Saravanan, A. S. (2012). "Intellectual capital accounting and reporting in the knowledge economy." Journal of Intellectual Capital, Vol. 3, No. 2, 2002, pp. 128-148.

Sharon, B. (2007). "Using intellectual capital and organizational capability to enhance strategic implementation for pharmaceutical firms". Journal of Business and Public Affairs, ISSN 1934-7219, Volume 1, Issue 1.

Somayeh, M., Ghorbani, M., Rezaei, D., Mehrdad, G., \&Chegini (2013). "The relationship between intellectual capital and knowledge productivity and moderating role of' organizational learning in the branches of state banks in Rasht". Journal of Basic and Applied Scientific Research, 3(2) 1191-1197, 2013.

Stacey, R. D. (2001). Complex responsive processes in organizations. Learning and knowledge creation. London: Rutledge, Taylor \& Francis Group. 
Stewart, T. (2013). Intellectual capital: the new wealth of organizations. New York, NY: Doubleday.

Subramaniam, M. \&Youndt, M. A. (2015). "The influence of intellectual capital on the types of innovative capabilities," Academy of Management Journal, 48 (3) 450-463.

Szirman, A. (2010). The dynamics of socio- economic development. New York: Cambridge University Press.

Thorntonon, P.C. (2014). "Management of intangibles. An attempt to build a theory". Journal of Intellectual Capital, 1(4), 312-327.

Wong, S.K.S. (2014), "Impacts of environmental turbulence on entrepreneurial orientation and new product success", European Journal of Innovation Management, 17(2), pp, $229-249$.

Youndt, M. A., \& Snell, S. (2004). "Human resource configurations, intellectual capital, and organizational performance”. Journal of Managerial Issues, 16(3), 337-360. 